\title{
IMPLEMENTASI LOAD BALANCING MENGGUNAKAN METODE PCC (PER CONNECTION CLASIFIER) DI UNIVERSITAS KRISNADWIPAYANA
}

\author{
Imam Sujarwo1; Desmulyati²; Imam Budiawan ${ }^{3}$ \\ 1,3 Teknik Informatika \\ 1,3,STMIK Nusa Mandiri \\ www.nusamandiri.ac.id \\ 1imamsujarwo@unkris.ac.id; 3imam.imb@nusamandiri.ac.id \\ ${ }^{2}$ Teknologi Komputer \\ Universitas Bina Sarana Informatika \\ www.bsi.ac.id \\ 22desmulyati.dmy@bsi.ac.id
}

\begin{abstract}
On the internet connection with 2 service ISP (Internet Service Provider) to consider the possibility of interruption on the internet connection. PCC (Per Connection Classifier) is a method of load balancing in the merge 2 ISP service. An Internet network connection is needed by a company or agency that performs each job with a depending internet network connection. It is, therefore, necessary internet networks are always standby when the failure occurs the internet connection. At this writing performed a system. First test done with 1 ISP service. Testing both with the use of PCC in the normal state and with the use of PCC occurs when lost connection on one of the links. By using 2 ISP services can be separated between local bandwidth and international done on the second test. On testing the second can be proved that by using the 2 service ISP with load balancing PCC and much better against the service connection network the internet because there is a system that is always on standby when it happened lost connection on one of the links. With system blocks, the IP automatically can protect the server MikroTik from attack hackers.
\end{abstract}

Keyword: Load Balancing, PCC, Filter Rules, Bandwidth

Abstrak - Pada koneksi internet dengan 2 layanan ISP (Internet Service Provider) perlu diperhatikan kemungkinan akan terjadinya gangguan pada koneksi internet. PCC (Per Connection Clasifier) merupakan metode load balancing dalam penggabungan 2 layanan ISP. Koneksi jaringan internet sangat dibutuhkan oleh sebuah perusahaan atau instansi yang melakukan setiap pekerjaan dengan bergantung koneksi jaringan internet. Oleh karena itu diperlukan jaringan internet yang selalu standby ketika terjadi kegagalan koneksi internet. Pada penulisan ini dilakukan sistem . Pengujian pertama dilakukan dengan 1 layanan ISP. Pengujian kedua dengan menggunakan PCC dalam keadaan normal dan dengan menggunakan PCC ketika terjadi lost koneksi pada salah satu link. Dengan menggunakan 2 layanan ISP dapat dipisahkan antara bandwidth lokal dan internasional yang di lakukan pada pengujian kedua. Pada pengujian kedua dapat dibuktikan bahwa dengan menggunakan 2 layanan ISP dengan load balancing PCC dan jauh lebih baik terhadap layanan koneksi jaringan internet dikarenakan terdapat sistem yang selalu siaga ketika terjadi lost koneksi pada salah satu link. Dengan sistem blok IP secara otomatis dapat melindungi server mikrotik dari serangan hacker.

Kata kunci: Load Balancing, PCC, Aturan Filter, Bandwidth

\section{PENDAHULUAN}

Kebutuhan komunikasi sangat penting seiring dengan kemajuan dan perkembangan teknologi komunikasi data yang semakin berkembang pesat. Dalam memenuhi kebutuhan akan teknologi komunikasi data, administrator jaringan harus bijak dalam memilih Internet Service Provider (ISP) yang akan kita gunakan. Menggunakan dua ISP atau lebih dapat dijadikan solusi untuk memenuhi kebutuhan internet. Load balancing merupakan salah satu teknik routing yang dapat memanfaatkan beberapa ISP untuk dapat digunakan secara bersamaan atau saling membackup jika ISP lainnya down atau bermasalah. Ada berbagai metode yang dapat digunakan, salah satunya adalah metode $\mathrm{Per}$ Connection Classifier (PCC). (Pangestu, Setiyadi, \& Khasanah, 2018).

Jaringan Komputer merupakan salah satu cara penerapan teknologi informasi yang berkembang cepat. Dewasa ini hampir setiap perusahaan menggunakan jaringan komputer untuk berkomunikasi dengan pihak - pihak yang membutuhkan dengan memberikan izin akses. 
(Rahmawati, 2015). Universitas Krisnadwipayana memiliki permasalahan jaringan dari sisi penggunaan satu penyedia internetnya (ISP) (Haryanto \& Riadi, 2014) yaitu seringkali mengalami ganguan (Oktivasari \& Sanjaya, 2015) seperti adanya perbaikan pada layanan, tiba tiba koneksi internet terputus (Ikhsanto, 2016) yang dapat menghambat pekerjaan yang membutuhkan koneksi internet karena hanya menggunakan satu layanan yang mengakibatkan semua traffic dibebankan pada ISP tersebut yang mengakibatkan overload (Oktivasari \& Sanjaya, 2015) karena terlalu banyak beban traffic yang dilewati dan tidak adanya filtering akses pada client.

Oleh karna itu dibutuhkan perancangan dan implementasi dengan menggunakan dua layanan ISP dengan metode load balancing PCC dan Failover agar tidak terjadi gagalnya koneksi karena hanya menggunakan satu layanan servis internet dan membagi beban traffic pada ISP. Load Balancing merupakan salah satu teknik routing yang dapat memanfaatkan beberapa sumber daya internet untuk dapat digunakan secara bersamaan (Sukendar, 2017)

Berdasarkan uraian tersebut maka terdapat suatu kebutuhan untuk mengatur Load Balancing pada lebih dari satu jalur internet atau ISP dan mengoptimalkan bandwidth yang di berikan oleh ISP yaitu dengan metode PCC, dimana bandwidth merupakan nilai hitung atau perhitungan konsumsi transfer data telekomunikasi yang dihitung dalam satuan bit per detik (bps) yang terjadi antara komputer server dan komputer client dalam waktu tertentu dalam sebuah jaringan computer. (Muhammad \& Hasan, 2016) Mekanismenya yaitu mikrotik akan menandai paket yang ingin mengakses internet, lalu menyetarakan beban pada kedua ISP dan akan memilih jalur ISP mana yang akan dilewatinya. Penelitian ini bertujuan untuk mengimplementasikan dua layanan ISP dengan metode load balancing PCC dan Failover agar tidak terjadi gagalnya koneksi karena hanya menggunakan satu layanan servis internet dan membagi beban traffic pada ISP.

\section{BAHAN DAN METODE}

Dalam membangun sebuah jaringan komputer dibutuhkan ketepatan dalam memilih skema jaringan sehingga dapat digunakan secara efektif dan efisien. Seperti pemilihan topologi jaringan, jenis jaringan dan perangkat jaringan yang akan dipakai. (Lukman \& Bachtiar, 2018). Tujuan penggunaan metode PCC (Peer Connection Classifier) digunakan untuk memberikan alternatif solusi jaringan pada Universitas Krisnadwipayana, dengan melakukan observasi berupa pengumpulan data-data tentang alat-alat yang digunakan perusahaan dalam pemasangan jaringannya, lalu dikelompokkan dengan metode Load balancing, yaitu mengelompokan trafik koneksi melalui atau keluar masuk router menjadi beberapa kelompok (Adani, Jusak, \& Pratikno, 2016).

Tahapan metode penelitian dimulai dari: membuat analisa kebutuhan, memaparkan beberapa perangkat yang sangat penting dan merupakan kebutuhan utamanya, dua buah koneksi internet dari dua ISP yang berbeda, satu buah router mikrotik, winbox, dan mikrotik software. Mendesain topologi jaringan, dan skema jaringan, dengan melakukan berbagai konfigurasi baik pada mikrotik Routerboard, PCC dan Failover, serta IP Address dan mangle, konfigurasi pembagian bandwidth Internasional dan Lokal, berikutnya testing jaringan dari keadaan link normal pada awal metode PCC sampai keadaan gagal link, dan melakukan simulasi pada winbox.

\section{HASIL DAN PEMBAHASAN}

Langkah awal perancangan PCC dan failover adalah melakukan konfigurasi dasar seperti pengalamatan IP address kemudian konfigurasi PCC dengan mengatur mangle untuk menandai koneksi dengan mengarahkan koneksi client kedua jalur ISP1 dan ISP2 , setelah konfigurasi selesai dilakukan pengetesan dengan test ping untuk memastikan konfigurasi PCC sudah berjalan dengan baik.

Ketika konfigurasi PCC sudah berhasil, kemudian dilakukan konfigurasi failover dengan mengatur ip route untuk menandai trafik ISP1 menjadi diutamakan, lalu melakukan uji coba dengan mematikan salah satu ISP. Sehingga apabila ada salah satu IPS yang kecepatan transfer data bernilai 0 (bps) atau down maka seluruh trafik akan dialihkan ke ISP yang aktif.

\section{Topologi Jaringan}

Untuk membangun suatu jaringan
dibutuhkan perancangan topologi dan
pengimplementasiannya kedalam jaringan. Berikut
adalah topologi jaringan untuk merancang dan
mengimplementasikan load balancing dan
menggunakan metode PCC:




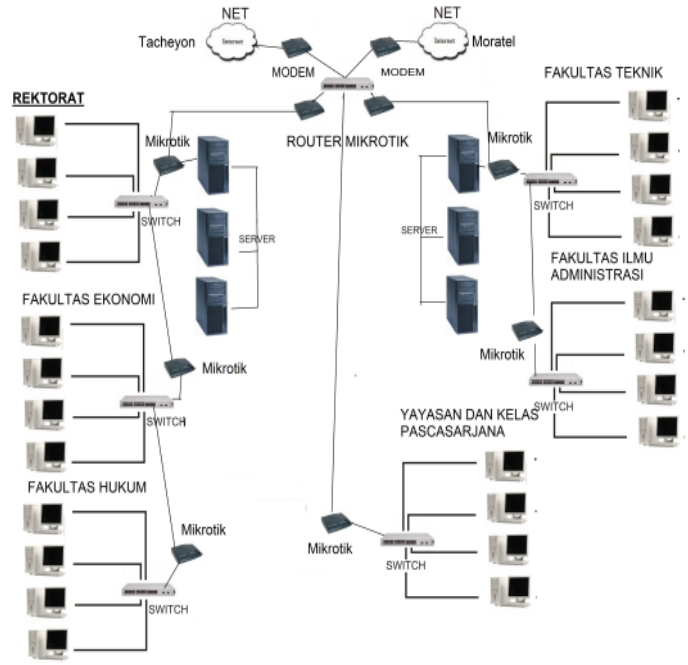

(Sujarwo, Desmulyati, \& Budiawan, 2019)

Gambar 1. Topologi Jaringan Load Balancing 2 ISP Menggunakan Metode PCC

Menggambarkan topologi yang digunakan untuk membangun load balancing dan menggunakan metode PCC (Peer Connection Classifier) pada jaringan 2 ISP, berikut adalah penjelasan gambar topologi jaringan pada gambar 1:

1. Topologi yang digunakan adalah topologi star karena topologi star paling mudah dianalisa ketika ada kegagalan koneksi internet.

2. Routing yang dilakukan pada topologi ini dapat menghasilkan 2 jalur koneksi

3. ISP Tacheyon dan ISP Moratel dihubungkan dalam satu jaringan yang menggunakan metode load balancing .

4. Pada ISP Tacheyon dikhususkan untuk bandwidth internasional sedangkan ISP Moratel dikhususkan untuk bandwidth lokal.

5. Perangkat yang digunakan dalam topologi ini adalah mikrotik,ISP, dan client yang terdiri dari ISP Tacheyon menjadi jalur koneksi utama ISP Moratel sebagai jalur kedua.

6. IP address yang digunakan pada topologi ini adalah versi 4 (IPv4) dan merupakan IP address kelas C karena implementasi jaringan ini menggunakan topologi yang sederhana.

\section{Keamanan Jaringan}

Keamanan Jaringan yang ada di Kampus Universitas Krisnadwipayana berupa proxy, firewall, yang bekerja untuk mencegah dan menghalau virus ataupun ancaman peretas yang bisa saja kapan pun misal meretas website kampus. Untuk mengamankan web server mikrotik dari serangan hacker maka dari itu dapat dilakukan dengan cara blok IP lokal secara otomatis yang dapat memutuskan semua koneksi yang ada.

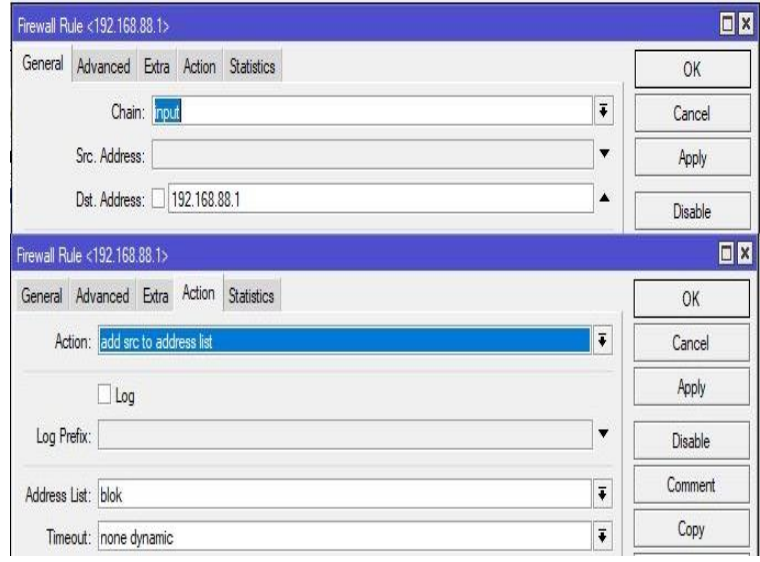

(Sujarwo et al., 2019)

Gambar 2. Konfigurasi menandai IP yang akan diblok pada firewall rule

\section{Pengujian Jaringan Awal}

Pengujian pertama dilakukan user menggunakan test ping. Untuk melakukan pengujian terhadap koneksi internet dengan menggunakan command prompt dan aplikasi chrome, dengan menggunakan metode PCC mikrotik dapat menandai jalur koneksi berdasarkan src address, dst address, src port dan dst port sehingga ketika client akses ke detik.com router mikrotik menandai berdasarkan port dan ip public yang digunakan oleh detik.com, sehingga ketika ada yang akses detik.com dari client lain maka request diarahkan ke jalur yang sudah ditandai oleh mikrotik.

\section{Winbox}

Sebelum masuk dan melakukan konfigurasi ke sistem, terlebih dahulu digunakan aplikasi WinBox untuk me-remote router. Dalam penggunaan aplikasi WinBox dibutuhkan alamat IP router, IP user beserta password dari router yang akan di remote.

Berikut konfigurasi IP Address pada router ISP1 Moratel:

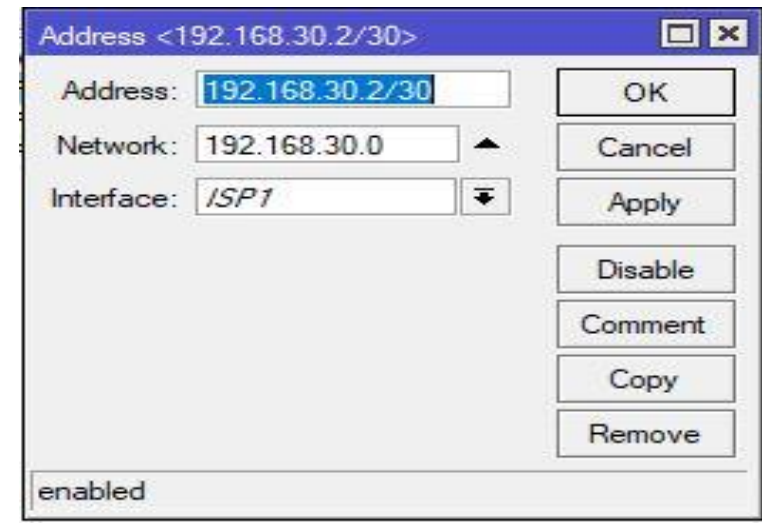

(Sujarwo et al., 2019)

Gambar 3. konfigurasi IP Address ISP Moratel 
Gambar diatas adalah pengalamatan IP Address pada ethernet 1 dengan IP 192.168.30.2/30 yang didapat pada ISP Moratel, setelah itu ganti nama interface menjadi ISP1.

Berikutnya adalah gambar pengalamatan IP Address pada ethernet 2 dengan IP 192.168.40.2/30 yang didapat pada ISP Tacheyon, setelah itu ganti nama interface menjadi ISP 2

\begin{tabular}{|c|c|c|c|}
\hline \multicolumn{3}{|c|}{ Address $\langle 192.168 .40 .2 / 30\rangle$} & $\square$ \\
\hline \multirow{7}{*}{$\begin{array}{l}\text { Address: } \\
\text { Network: } \\
\text { Interface: }\end{array}$} & \multicolumn{2}{|c|}{$192.168 .40 .2 / 30$} & \multirow{2}{*}{$\frac{\text { OK }}{\text { Cancel }}$} \\
\hline & 192.168 .40 .0 & - & \\
\hline & \multirow[t]{5}{*}{$1 S P 2$} & \multirow[t]{5}{*}{$\equiv$} & Apply \\
\hline & & & Disable \\
\hline & & & Comment \\
\hline & & & Copy \\
\hline & & & Remove \\
\hline enabled & & & \\
\hline
\end{tabular}

(Sujarwo et al., 2019)

Gambar 4. Konfigurasi IP Address ISP Tacheyon

\begin{tabular}{|c|c|c|c|}
\hline \multicolumn{3}{|c|}{ Address $\langle 192.168 .88 .1 / 24\rangle$} & $\square$ \\
\hline \multirow{7}{*}{$\begin{array}{l}\text { Address: } \\
\text { Network: } \\
\text { Interface: }\end{array}$} & \multicolumn{2}{|c|}{$192.168 .88 .1 / 24$} & OK \\
\hline & 192.168.88.0 & - & Cancel \\
\hline & etherl & $F$ & Apply \\
\hline & & & Disable \\
\hline & & & Comment \\
\hline & & & Copy \\
\hline & & & Remove \\
\hline enabled & & & \\
\hline
\end{tabular}

(Sujarwo et al., 2019)

Gambar 5. konfigurasi IP Address Ethernet 1

Gambar 5 diatas adalah pengalamatan IP pada ethernet 1 dengan IP 192.168.88.1/24 untuk IP client supaya dapat berinternet.

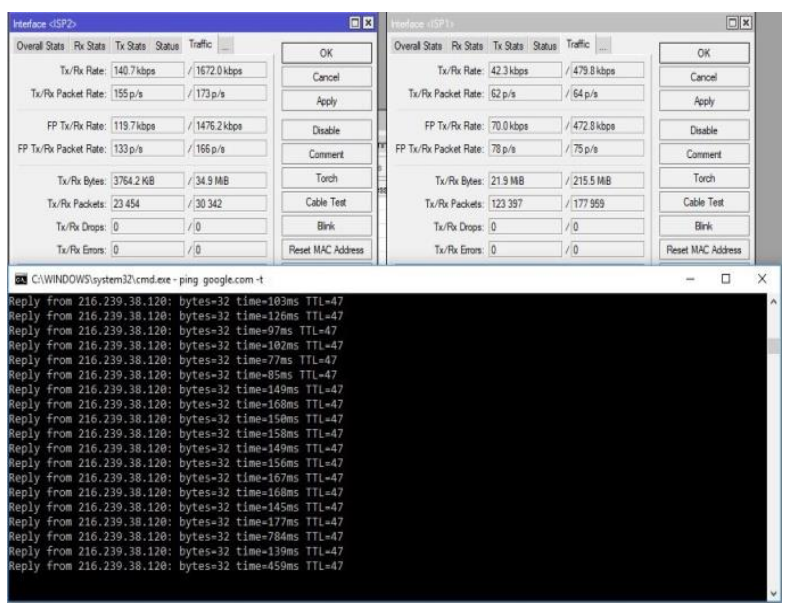

(Sujarwo et al., 2019)

Gambar 6. Test Ping Metode PCC Link Normal Menggunakan Command Prompt

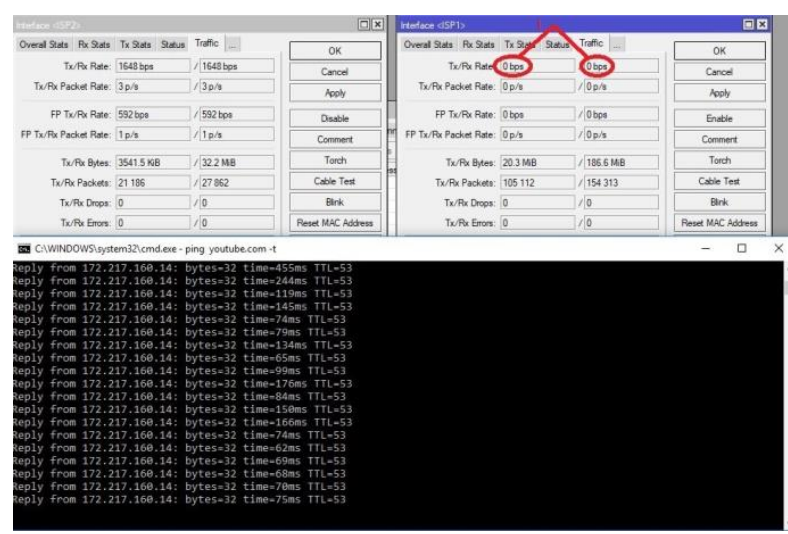

(Sujarwo et al., 2019)

Gambar 7. Test Ping PCC Keadaan Gagal Pada ISP Utama Menggunakan Command Prompt

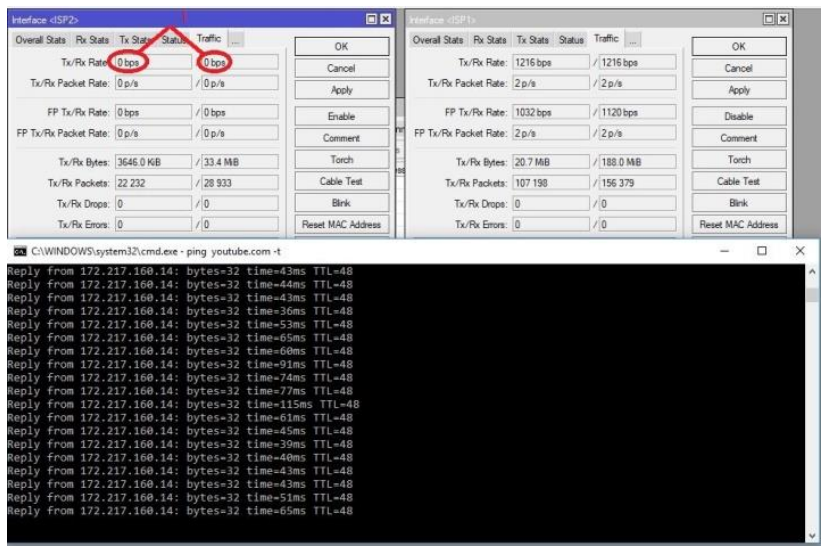

(Sujarwo et al., 2019)

Gambar 8. Test Ping PCC Keadaan Gagal Pada ISP back-up Menggunakan Command Prompt

\section{Pengujian Jaringan Akhir}

Pengujian jaringan akhir dari implementasi dilakukan untuk mengetahui berhasil atau tidak pemisahan bandwidth internasional dan lokal sesuai dengan skenario yang telah dibuat

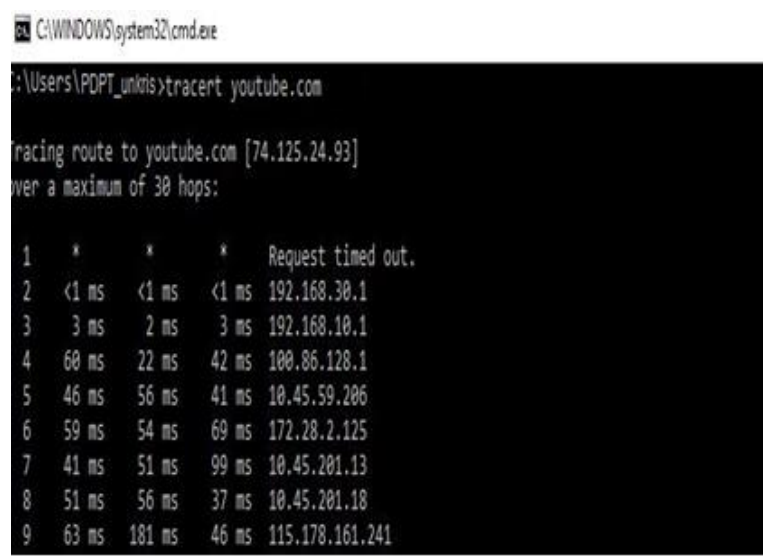

(Sujarwo et al., 2019)

Gambar 9. Capture Traceroute Bandwidth Internasional 
Pada gambar 9. trafik bandwidth internasional dengan akses youtube.com melewati ISP Andromax dengan IP address 192.168.30.1 yang telah dibuat untuk akses bandwidth internasional.

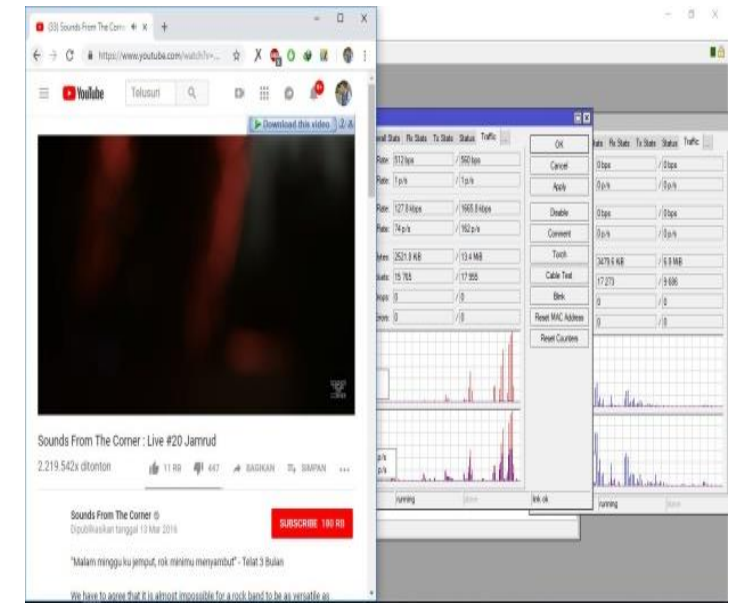

(Sujarwo et al., 2019)

Gambar 10. Capture Grafik akses Internet Internasional

Pada gambar 10 trafik pada ISP 1 terlihat tinggi karena pemisahan bandwidth internasional diarahkan ke ISP 1 dan pada trafik ISP 2 diarahkan bandwidth lokal.

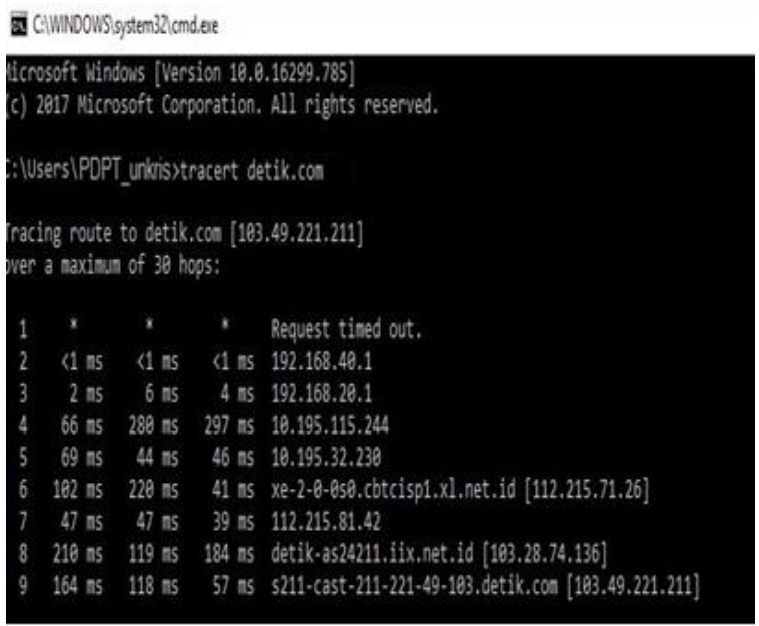

(Sujarwo et al., 2019)

Gambar 11. Capture Traceroute Bandwidth Nasional

Pada gambar 11. trafik bandwidth nasional dengan akses detik.com melewati ISP Moratel dengan IP address 192.168.40.1 yang telah dibuat untuk akses bandwidth nasional.

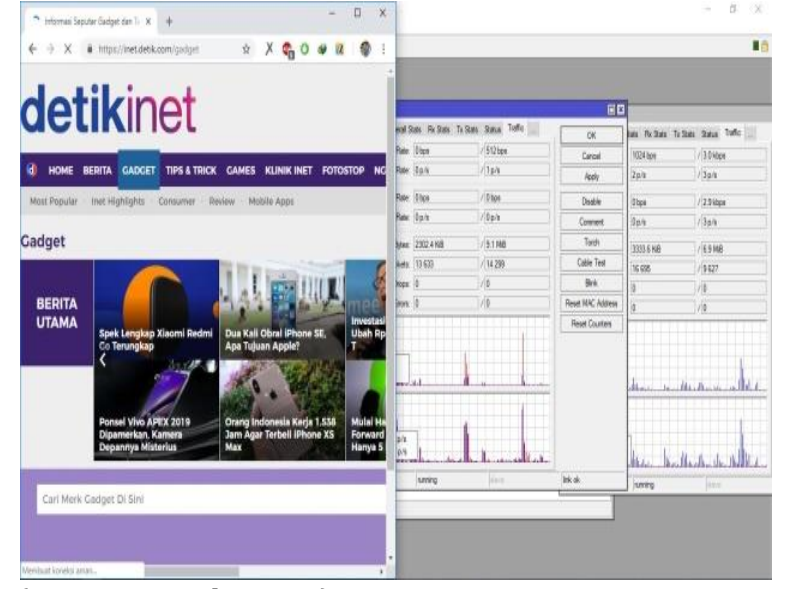

(Sujarwo et al., 2019)

Gambar 12. Capture Akses Internet Lokal

Pada gambar 12. trafik pada ISP 2 terlihat tinggi dan padat karena pemisahan bandwidth lokal diarahkan ke ISP 2 dan pada trafik ISP 1 diarahkan bandwidth internasional.

\section{KESIMPULAN}

Berdasarkan hasil percobaan yang dilakukan maka dapat disimpulkan beberapa hal diantaranya : Penggabungan 2 ISP dengan metode load balancing PCC membuat dapat dilakukannya pemisahan trafik sehingga router akan menetapkan berdasarkan src-address dan dst-address dari sebuah koneksi. Berdasarkan hasil pengujian Konfigurasi routing pada mikrotik yang dijalankan dengan metode PCC dalam mengatur trafik yang memiliki 2 layanan ISP, dapat berjalan dengan baik. Dan penerapan koneksi internet juga berjalan dengan baik ketika kedua ISP dalam keadaan hidup, Saat ISP 1 mengalami gagal koneksi, maka ISP 2 akan otomatis mengambil alih sehingga koneksi tetap berjalan dengan baik, begitu juga sebaliknya ketika ISP 2 mengalami gagal koneksi, maka ISP 1 akan otomatis mengambil alih sehingga koneksi tetap berjalan dengan baik. Dengan itu sistem berjalan dengan baik. Dan hasil pengujian pemisahan bandwidth internasional dan lokal Mikrotik dapat mengoptimalkan pembagian bandwidth internasional menuju ISP1 dan bandwidth nasional menuju ISP2. Pengamanan server mikrotik dengan cara block IP lokal ketika akses IP mikrotik maka server mikrotik aman dari serangan.

\section{REFERENS}

Adani, M. F., Jusak, \& Pratikno, H. (2016). Analisis Perbandingan Metode Load Balance Pcc Dengan Nth Menggunakan Mikrotik. Journal of Control and Network System, 5(1), 119125. 
Haryanto, M. D., \& Riadi, I. (2014). Analisis Dan Optimalisasi Jaringan Menggunakan Teknik Load Balancing (Studi Kasus: Jaringan UAD Kampus 3), 2, 295-304.

Ikhsanto, M. N. (2016). Analisis performa dan desain jaringan komputer menggunakan topdown network desainstudi kasus pada cv. merah putih, 16(2), 185-199.

Lukman, - Afit Muhammad, \& Bachtiar, - Yusuf. (2018). Analisis Sistem Pengelolaan, Pemeliharaan dan Keamanan Jaringan Internet Pada IT Telkom Purwokerto. Evolusi: Jurnal Sains Dan Manajemen, 6(2), 49-56.

https://doi.org/10.31294/evolusi.v6i2.4427

Muhammad, M., \& Hasan, I. (2016). Analisa Dan Pengembangan Jaringan Wireless Berbasis Mikrotik Router Os V.5.20 Di Sekolah Dasar Negeri 24 Palu. Jurnal Elektronik Sistem Informasi Dan Komputer, 2(1), 10-19. https://doi.org/2477-5290

Oktivasari, P., \& Sanjaya, R. (2015). Implementasi Sistem Load Balancing Dua ISP Menggunakan Mikrotik dengan Metode Per Connection Classfier, 1(2), 33-37.

Pangestu, Y., Setiyadi, D., \& Khasanah, F. N. (2018). Metode Per Connection Classifier Untuk Implementasi Load Balancing Jaringan Internet. PIKSEL: Penelitian Ilmu Komputer Sistem Embedded and Logic, 6(1), 1-8. https://doi.org/10.33558/piksel.v6i1.1389

Rahmawati, 2015 -. (2015). Konfigurasi Keamanan Jaringan Komputer Pada Router Dengan Metode Acl ' S. Teknik Komputer AMIK BSI. https://doi.org/10.31294/JTK.V1I2.246

Sujarwo, I., Desmulyati, D., \& Budiawan, I. (2019). Laporan Akhir Penelitian: Implementasi Load Balancing Menggunakan Metode PCC (Per Connection Clasifier) Di Universitas Krisnadwipayana. Jakarta.

Sukendar, T. (2017). Keseimbangan Bandwidth Dengan Menggunakan Dua ISP Melalui Metode Nth Load Balancing Berbasiskan Mikrotik. Jurnal Teknik Komputer Amik Bsi, III(1), 86-92. 